\title{
The relation of forest fertilization to disease incidence
}

\author{
GENE A. HESTERBERG and MARTIN F. JURGENSEN \\ Department of Forestry \\ Michigan Technological University \\ Houghton, Michigan
}

\begin{abstract}
La relation entre la fertilisation forestière et son incidence sur les maladies. Il existe un besoin d'informations relatives aux forêts traitées par fertilisants et de leurs effets sur la présence de maladies. L'auteur repasse et discute la littérature qui met en relief une évidence marquée de corrélations entre fertilisants, agents pathogènes des arbres et microflore du sol. De telles corrélations s'avèrent importantes en vue du contrôle de la maladie et doivent être considérées lorsque les forestiers songent à l'emploi de fertilisants pour accroitre la croissance.
\end{abstract}

Keen interest has developed in the use of chemical fertilizers in forest practice during the last two decades. Before this, fertilizers were normally re. stricted to use in forest nurseries which, as a result of prolonged production, became deficient in certain nutrients. ${ }^{35} 54$ The application of fertilizers in agriculture has long been an established practice, but broadscale use of fertilizer in North American forest stands is relatively new. An example is the Weyerhauser Company, which had no fertilization program in 1966 but plans to treat over 100,000 acres in $1975 .^{34} \mathrm{Swan}^{48}$ has summarized the advantages of the scientific use of fertilizer in forest practices. He states that the "toss it on and see what happens" approach to fertilization may yield disappointing results. Fertilization may increase tree growth, but it also changes the physiology of the tree and the chemical properties of the soil. Such changes in both the tree and the soil could alter the susceptibility of the tree to disease. It is the purpose of this paper to examine forest fertilization in light of its possible effects on tree disease incidence, and the mechanisms involved.

\section{Fertilizers and tree disease}

The relationship of plant nutrition to disease control is widely appreciated in agriculture. Fertilization

Based on a paper presented to the Third Annual Forestry Symposium, Lakehead University, Thunder Bay, Ontario, 13 February 1971. has been an accepted agronomic practice for many decades, and numerous investigations have shown its effects on disease incidence..$^{24}{ }^{51}$ In forestry, most studies of this type have centered on intensively managed nurseries. Since fertilizers are routinely used in nursery practice, management programs have been developed which take into account possible adverse effects of fertilization on seedling development. ${ }^{47}$ For example, the prevention of damping-off is of major importance and the application of nitrogen fertilizer makes the seedlings more susceptible. When nitrogen is used, fertilization is delayed until the seedlings have grown beyond the dampingoff stage or the minimum amount of nitrogen necessary to obtain adequate growth is used..$^{1045}$

The disease-nutrient relationship is less clear when applied to field situations. In a study ${ }^{8}$ on the influence of mineral nutrition to chestnut tree vigor and susceptibility to blight, Japanese chestnut was established as being more susceptible to blight as a result of applications of phosphorus and potassium. An application of nitrogen, phosphorus and potassium fertilizer to a young slash pine plantation produced significantly larger trees, but also increased the number of Cronartium-infected trees four-fold. ${ }^{4}$ After 19 years Cronartium infections were present on $65 \%$ of the fertilized pines whereas only $42 \%$ of the trees on control areas were infected. ${ }^{14}$ The fertilizer apparently caused the trees to break winter dormancy early. This early growth provides relatively large amounts of rust-susceptible tissue concurrent with peak production of rust spores, and at the time when weather conditions favor their germination (Siggers, in Boggess and Stahelin ${ }^{4}$ ). Significantly, stem cankers predominated in the fertilized plots, rather than the less-damaging branch cankers.

One of the major challenges to successful forest management is the control of root-rots such as Fomes annosus and Armillaria mellea. It has been 
established that the incidence of these diseases is changed by fertilization or liming (see Foster ${ }^{10}$ ). Infection by $\mathbf{F}$. annosus decreases with increasing soil potassium and magnesium content, but rises with increased manganese and soil $\mathrm{pH}^{.55}$ Nitrogen applications yield varying results, depending on the nitrogen level of the soil. A single, heavy application of nitrogen may have little effect on disease incidence. However, repeated amendments to the soil result in the accumulation of nitrogen which may create an imbalance of soil nutrients. Such imbalances have been shown to increase disease severity. ${ }^{12}$

Other studies have shown, however, that the addition of nitrogen may alleviate certain diseases. Roth et al. ${ }^{43}$ found that only soil amendments with large amounts of inorganic nitrogen were effective in controlling Littleleaf disease. Later, Roth and Copeland $^{42}$ demonstrated the relationship of fertilization to temporary recovery of shortleaf pine affected by Littleleaf disease. The destruction of unsuberized root tips by Phytophthora cinnamomi (the causative organism of Littleleaf disease) and the poor recovery of the damaged roots cause the trees to become nutrient-deficient. Added nitrogen temporarily reduces the pathogen-imposed deficiency rather than inhibiting the disease organism. ${ }^{56}$ Nitrogen fertilizer can also reduce the severity of Verticillum wilt of maple ${ }^{5}$ and maple decline. ${ }^{26}$ However, certain of the fungi involved (e.g. Verticillium and Phytophthora) are weak parasites and become pathogenic only when the physiology of the host tree is impaired by adverse stand, drainage, or other soil conditions. ${ }^{1}$ Soil management practices in relation to other disease have been discussed by Copeland. ${ }^{6}$

\section{Nutrient-plant-pathogen interactions}

A very important factor in disease resistance is the physiological condition of the plant. For example, vigorous trees are generally more susceptible to obligate parasites (such as rusts) while less susceptible to the facultative parasites. ${ }^{1023}$ Garrett $^{12}$ concluded that the effects of mineral nutrients on vascular wilt disease were due mostly to changes in host-plant physiology rather than directly effecting the pathogen in the soil. Physiological activity and resultant tree vigor is strongly affected by the internal nutrient balance. High levels of nitrogen usually increase the susceptibility of plants to both obligate and facultative parasites. This may be attributed to increased tissue succulence (which presumably facilitates parasite entry), production of a complex nitrogen source required by the pathogen, or to the reduction in the level of some metabolite produced by the plant which inhibits the pathogen. Conversely, high levels of phosphorus and potassium tend to decrease susceptibility, possibly by altering the nitrogen balance in the plant. ${ }^{17}{ }^{51}$ High amounts of iron in the roots of cotton were found to be associated with increased infection by Fusarium vasinfectum. ${ }^{46}$ Fertilization with manganese lowered the levels of iron in the roots and the incidence of Fusarium wilt was reduced. Iron is apparently important for the production of pectinolytic enzymes by the pathogen.

It is important to realize, however, that an increase in susceptibility to a disease due to fertilization may not necessarily lead to a high incidence of the disease. A good example is the take-all disease of wheat. High rates of fertilization increase the susceptibility of wheat roots to attack by the take-all fungus, but also increase the field resistance of wheat to the disease. The reason for this apparent paradox is that when nutrients are limiting, less roots are produced. When fertilizer is applied, many more roots are produced. Even if these roots are more susceptible to the fungus, random infection will still leave enough functional roots to support the plant. $^{12}$

Although fertilization apparently exerts its greatest influence on disease incidence through changes in the nutrient status of the plant, it also has a direct effect on the saprophytic ability and the resting stages of certain pathogenic fungi. Nitrogen, in particular, is important in the saprophytic survival of some root-rot fungi while not affecting others. In addition, levels of soil nitrogen appear to be important in regulating the formation and germination of Fusarium chlamydospores. ${ }^{12}$ The form of nitrogen applied as well as the amount is also important. Sclerotium production by Curvularia was favored by nitrate as compared to ammonium-nitrogen. ${ }^{46}$ However, nitrate is a poor nitrogen source for $\mathbf{F}$. annosus. ${ }^{21}$ This is true for other wood-destroying and root-rot fungi such as Poria weirii and $\mathbf{A}$. mellea.

\section{The rhizosphere}

The rhizosphere is that portion of the soil near and under the influence of plant roots. Due to the secretions and sloughings by roots, this region contains higher numbers and increased activity of microorganisms than root-free soil. ${ }^{44}$ Levels of certain mineral nutrients are higher in the rhizosphere than in the surrounding soil. ${ }^{41}$ The rhizosphere is also the site where soil-borne pathogens come in contact with plant roots. Garrett ${ }^{12}$ examined the relationship of root exudates to seedling diseases. He concluded that root exudates exert a direct effect on pathogens by $1 /$ stimulating the germination of resting stages, 2 / attracting both hyphae and zoospores to the root, and $3 /$ acting as energy sources for fungi. Differences in the microbial population of the rhizosphere have been reported between disease-resistant and disease-susceptible varieties of plants. ${ }^{38} 50$

Any treatment which changes conditions in the rhizosphere, such as the application of fertilizer, could alter the inoculum potential of the root pathogen. It has been found that fertilization and liming have a greater influence on the rhizosphere microflora than on microorganisms in the surrounding soil. $^{5253}$ Probably the best example of the effect of fertilization on the rhizosphere is the study by Timo$\operatorname{nin}^{49}$ on gray speck disease or manganese deficiency of oats. The application of manganese to the soil did not correct the deficiency, but nitrogen applied as calcium cyanamid did. Subsequent work showed 
that the rhizosphere of susceptible varieties contained large numbers of micro-organisms which oxidized manganese, making it unavailable to the plant. The application of cyanamid suppressed the activity of these organisms, thus increasing the amount of available manganese.

Fertilizers may affect the disease organism directly, through changes in the type or amount of root exudate, or alter the activity of other microorganisms antagonistic to the pathogen. For instance, nitrogen fertilizer increased the incidence of Fusarium wilt of cotton while phosphorus and potassium markedly reduced it. An examination of the rhizosphere microflora indicated that the percentage of microorganisms antagonistic to Fusarium was high with phosphorus and potassium treatment, and low where nitrogen was applied (Subbulakshmi, in Sadasivan). ${ }^{46}$ However, it was not possible to determine if antagonists were actually causing the reduction in disease incidence. The development of a competing or antagonistic microflora caused by the application of urea to fresh-cut tree stumps may also be a factor in the decrease of F. annosus infection. ${ }^{20}$

\section{Mycorrhizae}

In 1885 the term "mycorrhiza" was first used to describe the symbiotic invasion of tree roots by certain fungi. For decades since, scientists speculated on the importance of this root-fungus association to the growth of trees, particularly pines. With the advent of radioisotope techniques, the beneficial effects of mycorrhizae on water uptake, nutrient availability and overall tree growth have been well documented. ${ }^{13}{ }^{18}$ It is only recently that mycorrhizae have been implicated as a deterrent to the invasion of tree roots by soil-borne pathogens. Zak ${ }^{56}$, after reviewing past work on this subject, postulated that mycorrhizal fungi may protect the root by $1 /$ reducing carbohydrate levels in the root, 2 / acting as a physical barrier to infection, $3 /$ producing antibiotics, and 4 / favoring rhizosphere microorganisms which are inhibitory to pathogens.

Subsequent studies ${ }^{28}{ }^{30}$ have shown that mycorrhizal roots of loblolly and shortleaf pine are resistant to the attack of both zoospores and vegetative mycelium of P. cinnamomi. The mycorrhizae were found to produce an antibiotic and also acted as a physical barrier to the disease organism. An antibiotic produced by the mycorrhizae of pecan apparently acts as a deterrent to Pythium root infection. ${ }^{29}$ Other studies ${ }^{27}{ }^{37}$ have shown the production of antibiotics by mycorrhizal fungi, both in pure culture and when associated with the roots. Distinctive rhizosphere microflora have also been reported $^{22}{ }^{36}$ for mycorrhizal roots as compared to nonmycorrhizal roots. The possible significance of selective stimulation by mycorrhizae of organisms antagonistic to pathogens in the rhizosphere has been discussed by Foster. ${ }^{10}$

Since mycorrhizae may be important in reducing disease incidence, the effect of a fertilization program on their development and activity should be considered. Many studies with tree seedlings have shown that as the amount of available nitrogen increases, the degree of mycorrhizal infection de- creases. ${ }^{9113040}$ At high nitrogen levels, mycorrhiza formation may be suppressed completely. ${ }^{216}{ }^{19}$ The addition of phosphorus has also been reported to inhibit mycorrhizal development. ${ }^{1133}$

A carbohydrate surplus theory has been advocated by Bjorkman ${ }^{3}$ to explain this phenomenon. In this scheme the amount of nutrients taken up by the tree affects the amount of carbohydrate present in the roots. The lower the supply of nutrients, the higher the concentration of sugars in the root and the greater the mycorrhizal development. An inverse correlation has been found between nitrogen and sugar concentrations in the roots and mycorrhiza formation. ${ }^{40}$ The inhibition of mycorrhizae by phosphorus $^{11}$ may be due to an effect on the nitrogen content of the roots rather than to a direct effect of phosphorus per se.

In contrast to the above results, other studies $^{15}{ }^{19}{ }^{32}$ have indicated an increase in mycorrhizae as fertility increased. This effect may also be related to nitrogen levels of the tree, since Richards and Wilson $^{40}$ found phosphorus additions decreased the nitrogen concentration in the roots. The relationship of mycorrhizae to soil fertility has been pictured ${ }^{319}$ as a bell-shaped curve (Figure 1). Thus, when nuRELATIVE DEVELOPMENT

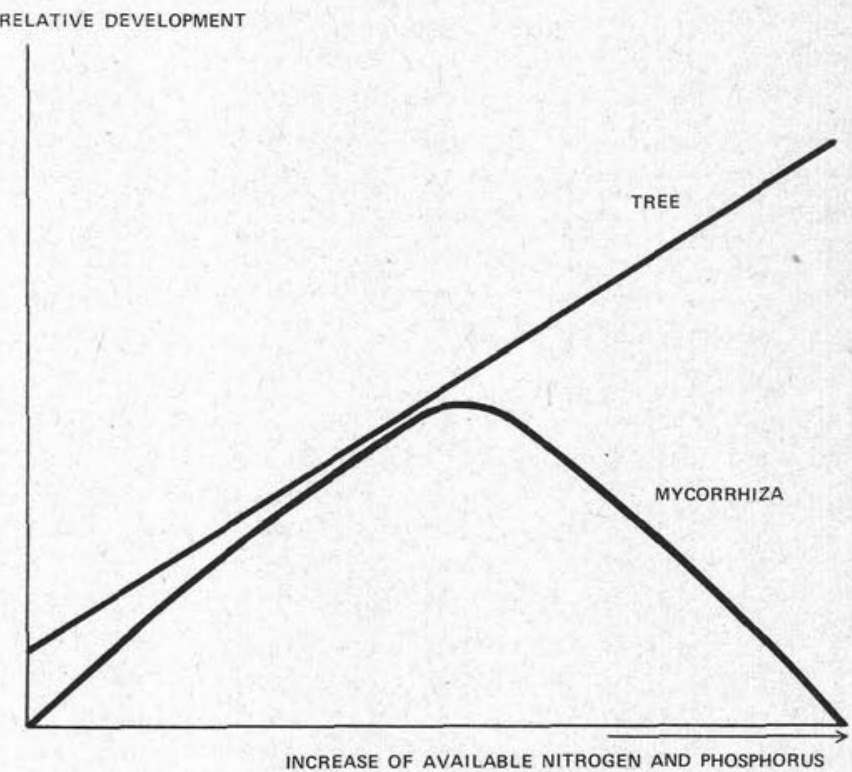

Fig. 1. Growth of conifers and the occurrence of ectotrophic nitrogen and phosphorus in the substrate. (From Biorkman ${ }^{3}$ ) mycorrhizae in relation to increasing amounts of available

trients are very deficient, an application of fertilizer will increase the percentage of mycorrhizal roots while on better sites, fertilization would decrease their frequency. However, even in field situations where heavy fertilization of soils occur, such as nurseries and seed tree orchards, the soil nutrient level is not raised high enough to completely eliminate mycorrhizae..$^{25}$

It is important to note that all experiments conducted on the effects of fertilizers on mycorrhizae have been on seedlings grown in nursery beds or greenhouse pots. The results may be entirely different when fertilizer is applied under forest conditions. For example, the addition of fertilizer to larger trees may not cause the great changes in root nitrogen levels found in small seedlings. Fertilization 
may also change the type of mycorrhizae found on the roots. ${ }^{15}$ What effect this would have on the mycorrhizae-disease relationship is unknown. Finally, and probably most important, it has not been established whether a reduction in the percentage of mycorrhizal roots increases the chances of disease attack.

\section{Conclusions}

No general rule can be made about the relationship of fertilization and disease resistance. Each disease must be evaluated individually, based on soil type, soil fertility and $\mathrm{pH}$. Fertilization changes both the nutrient status of the soil and tree. These changes may affect the resistance of the tree to disease attack or alter the development of pathogens in the soil. The main effect of fertilizers on disease organisms appears indirect - that is, by altering the metabolism and root exudates of the plant. Changes in rhizosphere populations and mycorrhizal development may also be factors, but definitive evidence is lacking.

The use of fertilizers in forestry should not be considered a panacea for improving the productivity of forest stands. Improved tree growth can be misleading if, by the same treatment, we increase disease incidence and tree mortality. However, there are situations where the application of fertilizers could increase tree growth while reducing susceptibility to a disease. At present, the increased productivity by far outweighs the few adverse effects from fertilization. As forest management becomes more intensive and fertilizers applied more frequently, the possible beneficial or adverse effects of a fertilization program on disease control will have to be considered.

\section{Literature cited}

1. BAXTER, D. V. 1967. Disease in forest plantations: thief of time. Cranbrook Inst. Bull. 51. 251 p.

2. BJORKMAN, E. 1970a. Mycorrhiza and tree nutrition in poor forest soils. Stud. For. Suec. 83. 24 p.

3. BJORKMAN, E. 1970b. Forest tree mycorrhiza - the conditions for its formation and the significance for tree growth and afforestation. Plant Soil 32: 589-610.

4. BOGGESS, W. R. and R. STAHELIN. 1948. The incidence of fusiform rust in slash pine plantations receiving cultural treatments. J. Forest. 46: 683-685.

5. CAROSELLI, N. E. 1956, The effect of various soil amendments on maple wilt incited by Verticillium sp. Abstr. in Phytopathology 46: 240.

6. COPELAND, O. L., Jr. 1960. Relation of forest diseases to soils and soil management. In Fifth World Forest Congr. Proc. p. 518-523.

7. COWLING, E. B. 1970. Discussions on Fomes annosus. In Proc. 3rd Int. Conf. Southeast. Forest Exp. Sta., Asheville, N. C. p. 192-201.

8. DILLER, J. D., C. W. WHITTAKER and M. S. ANDERSON. 1946. Effect of mineral nutrition on the vigor and susceptibility to blight of old Japanese chestnut trees. Phytopathology 36: 554-556.

9. DUMBROFF, E. B. 1968. Some observations on the effects of nutrient supply on mycorrhizal development in pine. Plant Soil 28: 463-466.

10. FOSTER, A. A. 1968. Damage to forests by fungi and insects as affected by fertilizers. In Forest fertilization theory and practice. Tenn. Valley Auth., Muscle Shoals, Ala. p. $42-46$.

11. FOWELLS, H. A. and R. W. KRAUSS. 1959. The inorganic nutrition of loblolly pine and virginia pine with special reference to nitrogen and phosphorus Forest Sci. 5: 95-112.

12. GARRETT, S. D. 1970. Pathogenic root-infecting fungi. Cambridge Univ. Press, Cambridge.

13. GERDEMANN, J. W. 1968. Vesicular-arbuscular mycorrhizae and plant growth. Ann. Rev. Phytopath. 6: 397-418.

14. GILMORE, A. R. and K. W. LIVINGSTON. 1958. Cultivating and fertilizing a slash pine plantation: effects on volume and fusiform rust. J. Forest. 56: 481-483.

15. GOBL, F. and H. PLATZER. 1967. (Fertilization and mycorrhizae development in young cembran pine). Mitt. For. Bundes-Vers. No. 74, 54 p.

16. HACSKAYLO, E. and A. G. SNOW, Jr. 1959. Relation of soil nutrients and light to prevalence of mycorrhizae on pine seedlings. USDA, Forest Serv., Northeast. Forest Exp. Sta. Pap. No. 125. 13 p.

17. HARE, R. C. 1966. Physiology of resistance to fungal diseases in plants. Bot. Rev. 32: 95-137.

18. HARLEY, J. L. 1970. Biology of mycorrhiza. 2nd Ed. Leonard Hill Books, London.

19. HATCH, A. B. 1937. The physical basis of mycotrophy in the genus Pinus. Black Rock Forest Bull. 6. 168 p.

20. HODGES, C. S. 1970. Evaluation of stump treatment chemicals for control of Fomes annosus. In Proc. 3rd Int. Conf. Fomes annosus. Southeast. Forest Exp. Sta., Asheville, N. C. p. $43-53$.

21. JOHANSSON, M. 1970. Discussions on Fomes annosus. In Session 6, Proc. 3rd Int. Conf. Fomes annosus. Southeast. Forest Exp. Sta., Asheville, N. C. p. 192-201.

22. KATZNELSON, H., J. W. ROUATT and E. A. PETERSON. 1962. The rhizosphere effect of mycorrhizal and nonmycorrhizal roots of yellow birch seedlings. Can. J. Bot. 40: $377-382$.

23. KOZLOWSKI, T. T. 1969. Tree physiology and forest pests. J. Forest 67: 118-123.

24. KRAUSS, A. 1969. (Effect of mineral nutrition of plants on the incidence of parasitic diseases and pests.) $Z$. PflanzEnernaehr. Bodenk. 124: 129-147.

25. LAIHO, O. and P. MIKOLA. 1964. Studies on the effect of some eradicants on mycorrhizal development in forest nurseries. Acta Forest Fenn. 77(2): 1-33.

26. MADER, D. L. and B. W. THOMPSON. 1969. Foliar and soil nutrients in relation to sugar maple decline. Soil Sci. Soc. Amer. Proc. 33: 794-800.

27. MARX, D. H. 1969. The influence of ectotrophic mycorrhizal fungi on the resistance of pine roots to pathogenic infections. 1. Antagonism of mycorrhizal fungi to root pathogenic fungi and soil bacteria. Phytopathology 59: 153-163.

28. MARX, D. H. 1970. The influence of ectotrophic mycorrhizal fungi on the resistance of pine roots to pathogenic infections. 5. Resistance of mycorrhizae to infection by vegetative mycelium of Phytophthora cinnamomi. Phytopathology 60: 1472-1473.

29. MARX, D. H. and W. C. BRYAN. 1969. Scleroderma bovista, an ectotrophic mycorrhizal fungus of pecan. Phytopathology 59: 1128-1132.

30. MARX, D. H. and C. B. DAVEY. 1969. The influence of ectotrophic mycorrhizal fungi on the resistance of pine roots to pathogenic infections. 4 . Resistance of naturally occurring mycorrhizae to infection by Phythophthora cinnamomi. Phytopathology 59: 549-558.

31. McNEW, G. L. 1953. The effects of soil fertility. In Plant diseases. USDA. Yearbook. p. 100-114.

32. MCVEAN, D. N. 1963. Growth and mineral nutrition of Scots pine seedlings on some cottom peat types. J. Ecol. 51: 657-670.

33. MITCHELL, H. L., R. F. FINN and R. O. ROSENDAHL. 1937. The relation between mycorrhizae and the growth and nutrient absorption of coniferous seedlings in nursery beds. Black Rock Forest Pap. 1: 58-73.

34. MORGAN, H. E., Jr. 1970. Timber growth: west and south. A comparison by industry. J. Forest $68: 425-429$.

35. MUSTANOJA, K. J. and A. L. LEAF. 1965. Forest fertilization research, 1957-1964. Bot. Rev. 31: 151-246.

36. NEAL, J. L., K. C. LU, W. B. BOLLEN and J. M. TRAPPE. 1968. A comparison of rhizosphere microfloras associated with mycorrhizae of red alder and douglas fir. Proc. Symp. "Biology of Alder." Northwest Sci. Ass. p. $57-71$. 
37. PARK, J. Y. 1970. Antifungal effect of an ectotrophic mycorrhizal fungus, Lactarius sp., associated with basswood seedlings. Can. J. Microbiol. 16: 798-800.

38. PETERSON, E. A. and J. W. ROUATT. 1967. Soil microorganisms associated with flax roots. Can. J. Microbiol. 13: 199-203.

39. RICHARDS, B. N. 1965. Mycorrhiza development of loblolly pine seedlings in relation to soil reaction and the supply of nitrate. Plant Soil 22: 187-199.

40. RICHARDS, B. N. and G. L. WILSON. 1963. Nutrient supply and mycorrhiza development in Caribbean pine. Forest Sci. 9: 405-412.

41. RILEY, D. and S. A. BARBER. 1970. Salt accumulation at the soybean (Glycine max (L.) Merr.) root-soil interface. Soil Sci. Soc. Amer. Proc. 34: 154-155.

42. ROTH, E. R. and O. L. COPELAND. 1957. Uptake of nitrogen and calcium by fertilized shortleaf pine. J. Forest. 55: 281-284.

43. ROTH, E. R., E. R. Toole and G. H. HEPTING. 1948. Nutritional aspects of the littleleaf disease of pine. J. Forest. 46: 578-587.

44. ROVIRA, A. D. 1965. Interactions between plant roots and soil microorganisms. Ann. Rev. Microbiol. 19: 241 266.

45. ROWAN, S. J. 1971. Soil fertilization, fumigation and temperature affect severity of black root rot of slash pine. Phytopathology 61: 184-187.

46. SADASIVAN, T. S. 1965. Effect of mineral nutrients on soil microorganisms and plant disease. In K. F. BAKER and W. C. SYNDER (eds.). Ecology of soil-borne plant pathogens. Univ. California Press, Berkeley. p. 460-469.

47. STONE, E. L., Jr. 1965. Nursery soil fertility. In Proc. Nursery Soil Improv. Sess. State Univ. N. Y. Col. Forest., Syracuse. p. 16-27.

48. SWAN, H. S. D. 1965. Reviewing the scientific use of fertilizers in forestry. J. Forest. 63: 501-508.

49. TIMONIN, M. I. 1964. Interaction of higher plants and soil microorganisms. In C. M. GILMOUR and O. N. ALLEN (eds.). Microbiology and soil fertility (Biology colloquium). Oregon State Univ. Press, Corvallis.

50. TIMONIN, M. I. 1966. Rhizosphere effect of healthy and diseased lodgepole pine seedlings. Can. J. Microbiol. 12: $531-537$.

51. TROLLDENIER, G. 1969. Cereal diseases and plant nutrition. Pot. Rev. 23/34: 1-16.

52. VOZNYAKOVSKAYA, YU, M. and N. P. AVROVA. 1968. Effect of fertilizers on reproduction of microorganisms producing vitamins in the rhizosphere of wheat. Mikrobiologiya 37: 110-114 (English translation).

53. WELTE, E., and G. TROLLDENIER. 1961. (The influence of the hydrogen ion concentration of the soil on the rhizosphere effect.) Naturwissenschaften 48: 509.

54. WHITE, D. P. and A. L. LEAF. 1956. Forest fertilization abstracts. State Univ., N. Y. Col. Forest., Syracuse, Tech. Publ. No. 81. 305 p.

55. YDE-ANDERSON, A. 1970. Discussions on Fomes annosus. In Session 4, Proc. 3rd Int. Conf. Fomes annosus, Southeast. Forest. Exp. Sta., Asheville, N. C. p. 177-184.

56. ZAK, B. 1964. Role of mycorrhizae in root disease. Ann. Rev. Phytopath. 2: 377-392.

FORESTER AVAILABLEForester, B.S. M.S. and Ph.D. desires position in research, teaching or administration. Broad training in silviculture ecology, soils, statistics, botany and plant physiology and geology. Major experience in site evaluation, growth and yield, land use assignment, reforestation, stripmine reclamation and recreation. Ten years with present employer in eastern Canada. Many publications. Available on reasonable notice.

\section{Potential for controlled-release fertilizers in forestry}

\section{P. O. SALONIUS}

Maritimes Forest Research Centre

Canadian Forestry Service

Fredericton, N.B.

\section{NELSON ADAMS}

Brunswick Peat Products Ltd. Fredericton, N.B.

\section{We report here on preliminary work with a controlled-release fertilizer formulation and discuss some advantages of this type of material in forestry to stimulate interest among experimenters and potential forest fertilizer users.}

In recent years, fertilizers have been used in several countries to increase forest growth. Controlledrelease fertilizers have been developed for use in agriculture and the rationale for their use in that industry is discussed in the recent papers of Lunt (1971) and Allen and Mays (1971). That there has been little active investigation in using controlledrelease fertilizers in forestry is illustrated by the fact that a reference list on the subject prepared in 1971 by the Commonwealth Bureau of Soils contained only 12 papers and most of these were concerned with the use of such materials in forest nursery practice. Slowly available forms of fertilizer that have been developed for agriculture and horticulture are both expensive and designed to make the fertilizer available to plants during a single growing season. Release in forestry is required through several seasons. The increase in cost of producing controlled-release fertilizer should be off-set by increases in efficiency (total nutrient availability) and growth (Ahmed et al. 1963, Allen and Mays 1971).

The major element used in coniferous forests that produce acid humus has been nitrogen, in the form of urea. Urea is readily soluble and subject to leaching losses (Gagnon 1971). It is also prone to rather large losses through ammonia volatilization (Carrier and Bernier 1971). Despite these liabilities, which have brought it into some disfavor in Scandinavia (Holman 1969), urea probably renders nutrients other than nitrogen more available due to its ability to increase the rate of organic matter decomposition and to shift the $\mathrm{pH}$ of the soil environment (Salonius 1972).

We felt that controlled-release urea might alleviate some of the disadvantages of conventional urea as a source of nitrogen while retaining the beneficial aspects. For example, leaching losses as well as luxury consumption should diminish; rootlet mortality and fixation of nitrogen in organic complexes should decrease since the treatment would be confined to an area adjacent to the fertilizer particle; and the release would be of sufficient duration for abundant tree roots to develop around the controlled-release particle in a position for maximum uptake (Raupach 1968). The controlled-release material thus may become a functional placement fertilizer and the large dosages that are necessary to 